\title{
Implementation of Online Gampong in The City Of Lhokseumawe
}

\author{
Muhammad Fazil*, Asrul Fahmi \\ Faculty of Social and Political Sciences, Universitas Malikussaleh, Aceh, Indonesia \\ *Corresponding author E-mail: mfazil@ unimal.ac.id
}

Manuscript received 1 Jan 2021; revised 10 Jan 2021; accepted 15 Jan 2021. Date of publication 20 Jan 2021

\begin{abstract}
This study is entitled "Implementation of Gampong Online in Lhokseumawe City". Where the strengthening of information and communication technology is still considered a luxurious facility and requires very large costs, so only a small part of the village government has obtained it. The wide gap between the size of the budget needs and the limited budget that can be provided gives rise to budget allocations that lead to physical activities for the development of rural infrastructure alone without looking at the increasingly rapid technological developments and increasing the capacity of village apparatus resources to support the current government system. both in the administrative system, public services as well as on matters relating to community business development. This study aims to see and describe the implementation of technology to present online gampongs with basic information and communication technology training activities for gampong governments in Lhokseumawe City. A descriptive qualitative approach with observation and documentation data collection techniques has been carried out in this study with field assessments in 3 (three) Gampongs in the Lhokseumawe city area to see the application of technology, determine strategy, socialize and provide information and communication technology introduction materials. The results of the study found that training for 3 (three) gampongs in the Lhokseumawe city government, namely Gampong Hagu Barat Laot, Gampong Hagu Teungoh and Gampong Hagu Selatan, had provided an understanding and awareness of the importance of using information and communication technology in gampong government for the smooth running of public services, public relations and public relations. internal organization as well as improving the business of the village community in the field of technology, where technology can help the village government connect with the city government and the village community online.
\end{abstract}

Keywords: Implementation, ICT, Online Village, Government.

\section{Introduction}

The development of information technology is experiencing a rapid revolution, especially for audiovisual devices, cellular phones, and computers. These technologies have changed the way people live and affect various aspects of people's lives [1] [2]. Advances in information and communication technology provide so many conveniences that allow everyone to communicate in all corners of the world. However To take advantage of these information and communication products, it is necessary for everyone to have special abilities in selecting, processing and absorbing useful information for the benefit of mankind [3] [4].

Portraits in Indonesia show how to reduce the digital divide between rural and urban areas. The central government issued a Presidential Instruction on the National Information and Communication Technology Action Plan [5]. This action plan states that information and communication technology should be used to empower citizens, improve their welfare, reduce poverty and eliminate the digital divide. However, the problem is that at the level of a more practical discussion, the use of information and communication technology is allegedly not able to answer the real problems of society [6] [7].

The facts on the ground show that the use of information and communication technology has not yet had an impact on improving the welfare of citizens or for systemic legal reform [8]. The cause, the delay in the progress of the application of information and communication technology in the community, among others, is caused by human resources factors that are not ready to adopt properly. The failure was also caused by the actors involved being too focused on technology development and forgetting the non-technical or human aspects. In the study, it was explained that information-based and Internet-aware village development programs in Indonesia are always faced with various problems, ranging from budgetary, technological to cultural aspects. This also happened in the province of Aceh, as well as in the city of Lhokseumawe [9].

Lhokseumawe City with an area of $181.06 \mathrm{~km} 2$. Which consists of 4 sub-districts, with each area as follows: Blang Mangat: $56.12 \mathrm{Km} 2$, Muara Dua: 
57.80 Km2, Muara Satu: $55.90 \mathrm{Km} 2$ and Banda Sakti: $11.24 \mathrm{Km} 2$. Has 68 gampongs (villages), has economic activities such as processing industry $20.74 \%$, trade, hotels and restaurants $24.77 \%$, mining and quarrying $0.95 \%$, building $4.40 \%$, transportation and communication $16.50 \%$, electricity, gas and clean water $0.17 \%$, services $4.40 \%$, finance $1.09 \%$, and agriculture $26.98 \%$. In terms of regional finance, Lhokseumawe City is not only the center of government, education and the economy, it is also a trade center. There were 775 goods and service companies carrying out their activities in Lhokseumawe City in 2001. In addition to large companies, medium and large business traders

Small scale micro scale seems to color the economic life in the trade sector which is booming in most people in Lhokseumawe City. (Central Bureau of Statistics of Lhokseumawe City, 2020)

This development certainly makes the city of Lhokseumawe one of the advanced cities in the province of Aceh at the district/city level in Aceh today. However, the level of urgency in implementing technology in government, especially information and communication technology to realize online government is still considered a necessity and luxurious facility and requires very large costs. The wide gap between the size of the budget requirement and the limited budget that can be provided creates a budget allocation that does not fully support the use of the best technology in government management. This is especially in the system of administration, public services and online-based community business improvement. Moreover, the available funds are more focused on other activities that are indeed a development priority in Lhokseumawe City, namely the transportation, education and health sectors.

The geographical condition of Lhokseumawe City which is close to the Malacca strait sea and has 4 (four) sub-districts with different areas of progress, is quite difficult to direct the budget towards greater technology. Furthermore, another problem that later emerged was the lack of existing resources which became one of the unpreparedness of the implementing apparatus in implementing and managing information and communication technology in the city of Lhokseumawe.

\section{Literature Review}

The word technology literally in Latin is texere, which means compiling or building, so the term technology should not be limited to the use of machines, although in a narrow sense it is often used in everyday life. In a broader sense, technology can include: understanding systems, organizations, as well as techniques. Technology refers to objects that are used to facilitate human activities, such as machines, tools, or hardware [10]. Technology can include: understanding systems, organization, as well as techniques. However, along with the development and progress of the times, the notion of technology is becoming increasingly widespread, so that currently technology is a concept related to the type of use and knowledge of tools and skills, and how they can affect the human ability to control and change what is around them. Furthermore, stated that technology aims to facilitate the fulfillment of human needs [11].

Along with the development and progress of the times, the notion of technology is becoming increasingly widespread, so that today technology is a concept related to the type of use and knowledge of tools and skills, and how it can affect the human ability to control and change things around them. So technology is a kind of extension of the human hand to be able to take full advantage of nature and the things around him. Thus, technology simply aims to facilitate the fulfillment of human needs [12].

The term information technology became popular in the late 70s. In the past, the term information technology was known as computer technology or electronic data processing or EDP (Electronic Data Processing). According to the Oxford dictionary, information technology is the study or use of electronic equipment, especially computers, to store, analyze and distribute any kind of information, including words, numbers and pictures. Information technology is a technology used to process data, including processing, obtaining, compiling, storing, manipulating data in various ways to produce quality information, namely information that is relevant, accurate and timely, which is used for personal, business and government purposes. which is a strategic aspect for decision making [13].

Information Technology according to Richard Weiner in Webster's New Word Dictinonary and Communication stated that Information Technology is the processing, processing, and dissemination of data by a combination of computers and telecommunications. Information Technology is a technology used to process, process, obtain, compile, store, manipulate data in various ways to produce quality information, namely information that is relevant, accurate and timely [14].

Information and communication technology today is very important because many government organizations have implemented information and communication technology to support organizational activities [15]. Information Technology and communication has a major role in the organization, namely to improve: Efficiency Effectiveness; Communication; and Competitive [16]. Information and communication technology is more applicable to the management of data and information within a company, with the use of computer technology and data communication, it will further increase productivity and work effectiveness. Currently, information technology is developing very quickly. Almost all areas of life and industry have been touched by information technology, be it entertainment, health, education, banking and even government activities or better known as electronic government [17].

The use of information and communication technology by the government, such as using intranets and the internet, which has the ability to connect the needs of the population, business and other activities, is a process of business transactions between the public and the government through automation systems and internet networks, more commonly known as the world wide web. (www). In the development of globalization and information and communication technology has also presented a flow of communication processes in organizational and management changes both in government and in business institutions [18]. These organizational changes require a different perspective on the position and role of human resources. The new perspective that positions human resources is more strategic and vital than the old perspective. The communication system began to flow with various patterns. One of these ways is to define the structure as a system through which messages flow or flow of communication within the organization .

Several studies on the development of information and communication technology in the field of government were reviewed with the title Optimizing the Implementation of E-Government through Social Media in Realizing Good Governance. Finding that the implementation of e-government has not been maximized, it can be seen from Indonesia's EGDI (E-Government Development Index) ranking which is still low. Barriers to information and communication technology infrastructure have introduced social media in the implementation of e-government. In the Utilization of Information and Communication Technology (ICT) at the Village Government Level. Finding that the development of information and communication technology at the village level is mostly still at the information stage, and a small part is in the interaction stage and to disseminate or disseminate information about activities development activities. Furthermore, Realization of Information and Communication Technology (ICT) Innovation in Several Aceh Districts (Study Lhokseumawe City). This study sees that the development of information and communication technology must also be supported by the development of human resources. From some of the results of the research above, in this service the solution offered to solve the problems faced is how to provide an understanding of the importance of using information and communication technology in govern- 
ment, especially village government. Where good use of technology will have an impact on the process of public service and administration systems that are effective and efficient [13].

\section{Method}

Gampong Hagu Barat Laot, Gampong Hagu Teungoh and Gampong Hagu Selatan, Banda Sakti District, Lhokseumawe City, Aceh Province were chosen as places of partnership-based community service in 2020 from 68 villages in Lhokseumawe City. Devotion in efforts to strengthen gampong government will apply technology in online administrative management in Banda Sakti sub-district, Lhokseumawe City, Aceh Province for Gampong Online. These three villages are villages that are close to each other in the coastal area of the city of Lhokseumawe, so far they already have supporting tools (hardware) for the application of information and communication technology in the implementation of their government. Method Activities by conducting observations and mapping (assessment) on villages and government officials who still do not understand the use of information and communication technology, technology development, and improving the quality and quantity of online-based services.

\section{Result and Discusion}

Online is a condition or activity that utilizes internet devices. This condition is unique, because of the necessity to have an information technology network using computer equipment, in addition to knowledge of computer programs to access information. online means using telecommunications and multimedia-based media (computers and the internet), such as portals, websites (websites, including blogs and social media such as facebook and twitter), online radio, online tv, and email. (Romli, 2014:30). Media

Online media has the characteristics and advantages of online media compared to conventional media (print/electronic).

From the community service activities carried out in 3 (three) Gampongs, starting with the steps mentioned in the methodology chapter, which includes several stages with the results obtained, namely the Need Assessment/mapping stage on the government conditions of the villages that are the object of training., it was found that the three gampongs that became the location of service had used several information and communication technology equipment such as the availability of desktop computers, notebooks, printers and scans, projectors and wifi networks which were paid for every month by the village government. Currently, the ICT equipment is only used for typing letters and storing files. Meanwhile, the service process is still manual by filling out forms and manual administrative requirements for paper documents. The internet network is mostly used for searching regulations and new letter formats which are used as a reference for correspondence only.

Furthermore, the letter archive is still in the paper (hard) folder, not yet in the soft data stored in folders on the computer. The use of the projector itself is only at certain meetings, such as the gampong musrembang and exposure to the revised APBG. There is no network between computers either internally in one room or in different rooms in one office. For the development of information and communication technology properly, there has been no initiative to establish a separate field and budget. However, in terms of information dissemination and communication, it is fast with the use of smartphones with the WhatsApp social media application.

From several observations in the gampong government, the available ICT equipment has not been fully utilized according to its function because understanding of technology is still lacking, especially in information and communication technology in government. Therefore, the next main strategy is to provide basic training on understanding the current use of information and communication technology to improve services and administration in government, especially the gampong government, which will deal directly with the community. The next step is to compile the material that will be delivered to the village government apparatus to be able to utilize technology to facilitate the service and administration of the village properly. The next stage is the provision of material in the form of

Basic Information and Communication Technology-Based Gampong Government Training activities in Lhokseumawe City for 3 (three) Gampongs namely South Hagu Village, Hagu Teungoh Village and West Laot Village Hagu were held at the Lancang Garam postgraduate campus, Lhokseumawe City on Tuesday, November 24, 2020. Training activities This event was attended by 16 participants with the presence of 15 people including 4 (four) participants from Gampong Hagu Selatan, 5 (five) participants from Gampong Hagu Teungoh, 5 (five) participants from Gampong Hagu Barat Laot and 1 (one) from Gampong Facilitator/Village in the use of Village Funds.

In this activity, participants are given basic knowledge which includes the introduction of information and communication technology in general, the use of information and communication technology in the gampong government and also the development of ICT for empowering the gampong community. The event which was held in 1 (one) day was also to get input on the use of technological equipment in the three villages so far, the development of village potential and creative industry values in the village, which were then given solutions to strengthen the ease of village-based governance. technology, especially information and communication technology in providing services and promotions.

This activity received a positive response from participants who so far have not understood well the functions and benefits of information and communication technology in gampong government. This lack of understanding has an impact on the allocation of even a small budget for its development in the gampong government. With this kind of training, there has been a positive response to changes in the APBG which has been oriented towards physical and building projects towards the development of information and communication technology in online-based gampong government. The hope is that this activity will continue in assisting the use of information and communication technology in the village by village facilitators in changing the village APBG in realizing an online village in the city of Lhokseumawe.

\section{Conclusion}

The implementation of online gampongs in Lhokseumawe City is a form of study in the implementation of community service, which can then be concluded that the observation activities carried out in 3 (three) Gampongs in Lhokseumawe City show that the use of technological equipment is only for typing letters and utilizing online via wifi to send email only. However, the correspondence process is still manual by presenting the form of filling paper and paper blanks. Furthermore, basic training for the Gampong government apparatus is carried out with basic knowledge material which includes the introduction of information and communication technology in general, the use of information and communication technology in the village government and also the development of ICT for village community empowerment. The event which was held in 1 (one) day was also to get input on the use of technological equipment in the three villages so far, the development of village po- 
tential and creative industry values in the village, which were then given solutions to strengthen the ease of village-based governance. technology, especially information and communication technology in providing services and promotions.

\section{References}

[1] Y. (朱艳) Zhu, “Maoming Ethylene Company brain drain and salary management,” 2008.

[2] M. Tubagus, S. Muslim, and Suriani, "Development of learning management system-based blended learning model using claroline in higher education," Int. J. Interact. Mob. Technol., vol. 14, no. 6, pp. 186-194, 2020, doi: 10.3991/IJIM.V14I06.13399.

[3] D. Napitupulu, M. Syafrullah, R. Rahim, D. Abdullah, and M. I. Setiawan, "Analysis of user readiness toward ICT usage at small medium enterprise in south tangerang," in Journal of Physics: Conference Series, 2018, vol. 1007, no. 1, doi: 10.1088/17426596/1007/1/012042.

[4] K. Rislana, A. Good, C. Adams, and P. Scott, "The role of ICT education and trainings in poverty reduction and economic empowerment: A case study of Jigawa state government ICT4D intervention," in Proceedings of the European Conference on eGovernment, ECEG, vol. 2016-January, 2016.

[5] T. Finster, “H\&M's Cambodian Garment Workers Are Only Asking for \$177 per Month: Why Can’t They Get It?,” jezebel.com, 2015. .

[6] D. Napitupulu et al., “Analysis of Technology Acceptance Model (TAM) on E-Learning System,” 2018, doi: 10.2991/icedutech17.2018.49.

[7] D. Abdullah and H. Fithra, "Mass Evacuation Transportation Model Using Hybrid Genetic Algorithm," Int. J. Adv. Sci. Eng. Inf. Technol., vol. 11, no. 3, 2021, doi: 10.18517/ijaseit.11.3.11687.

[8] N. Pheeraphan, "Enhancement of the 21st Century Skills for Thai Higher Education by Integration of ICT in Classroom," Procedia - Soc. Behav. Sci., vol. 103, pp. 365-373, 2013, doi: 10.1016/j.sbspro.2013.10.346.

[9] R. Siva Sankara Raju, A. D, and P. Thimothy, "Determination of Stress and Deformations Analysis on LPG Steel Cylinder," Int. J. Eng. Res. Appl., vol. 3, no. 1, 2013.

[10] S. B. M. K. Asilah Emir, Hazwani Halim, Asyikin Hedre, Dahlan Abdullah*, Azila Azmi, "Factors Influencing Online Hotel Booking Intention: A Conceptual Framework from Stimulus-Organism-Response Perspective," Int. Acad. Res. J. Bus. Technol., 2016.

[11] N. Afrian Nuari et al., "Caring of Disabilities Deaf Mute Patient with Talking Devices Application Based on Mobile," Int. J. Eng. Technol., 2018, doi: 10.14419/ijet.v7i3.6.17488.

[12] E. Rudnicka, P. Napierała, A. Podfigurna, B. Męczekalski, R. Smolarczyk, and M. Grymowicz, "The World Health Organization (WHO) approach to healthy ageing," Maturitas, vol. 139, 2020, doi: 10.1016/j.maturitas.2020.05.018.

[13] R. R. Sampaio, C. P. Rosa, and H. B. De Barros Pereira, "Mapeamento dos fluxos de informação e conhecimento: A governança de TI sob a ótica das redes sociais," Gest. e Prod., 2012, doi: 10.1590/S0104-530X2012000200011.

[14] K. Tsaurai and B. Chimbo, "Technology, Poverty, and Education within the BRICS' Context," Int. J. Econ. Bus. Adm., vol. VIII, no. Issue 4, 2020, doi: 10.35808/ijeba/600.

[15] R. S. Wibisono, T. D. Sofianti, and S. Awibowo, "Development of A Web-Based Information System for Material Inventory Control: The Case of An Automotive Company," CommIT (Communication Inf. Technol. J., vol. 10, no. 2, 2016, doi: 10.21512/commit.v10i2.1579.

[16] J. H. Mustakini, "Sistem Informasi Teknologi," Yogyakarta Andi Offset, 2009.

[17] A. A. Erumban and D. K. Das, "Information and communication technology and economic growth in India," Telecomm. Policy, vol. 40, no. 5, pp. 412-431, 2016, doi: 10.1016/j.telpol.2015.08.006.

[18] B. Latif, M. N. Shahid, M. Zia, U. Haq, H. M. Waqas, and A. Arshad, "Impact of Corporate Governance on Firm Performance: Evidence from Sugar Mills of Pakistan," Eur. J. Bus. Manag., 2013. 